\title{
BATUCADA NO MORRO: A PRESENÇA DA RODA DE SAMBA NO CONTO ANA DAVENGA, DA AUTORA CONCEIÇÃO EVARISTO
}

\section{BATUCADA NO MORRO: THE PRESENCE OF THE SAMBA CIRCLE IN THE ANA DAVENGA SHORT STORY, BY AUTHOR CONCEIÇÃO EVARISTO}

\author{
Arlene Batista da Silva ${ }^{1}$ \\ Universidade Federal do Espírito Santo \\ Ana Carla Soares de Oliveira ${ }^{2}$ \\ Universidade Federal do Espírito Santo
}

\begin{abstract}
Resumo: Este artigo tem como objetivo levantar discussões acerca da presença da roda de samba no conto Ana Davenga (1995), de Conceição Evaristo, a partir dos aspectos da tradição histórica. Inicialmente, reconhece-se a importância do samba como forma de divertimento para as comunidades afro-brasileiras, tendo em vista as influências culturais oriundas da África. Assim, busca-se apoio nos referenciais teóricos de Hermano Vianna na obra O Mistério do Samba (1995), Feitiço Decente (2012) de Carlos Sandroni, O terreiro e a Cidade (2002), de Muniz Sodré, entre outros. No conto Ana Davenga, a roda de samba compõe o espaço da narrativa como o lugar de divertimento e alegria ao passo das batucadas. Ancorado em uma análise literária, este artigo trouxe resultados reflexivos sobre as relações interartes - literatura e música, com destaque para o legado deixado pelos povos em nossa tradição musical.
\end{abstract}

Palavras-Chave: Ana Davenga; Literatura e samba; Literatura Afro-Brasileira.

1 Endereço eletrônico: arleneincrivel@gmail.com.

2 Endereço eletrônico: soaresanacarla2020@gmail.com. 
Abstract: This article aims to raise discussions about the presence of the samba circle in the short story Ana Davenga (1995), by Conceição Evaristo, from historical tradition aspects. Initially, the importance of samba is recognized as a form of entertainment for Afro-Brazilian communities, considering the cultural influences from Africa. Thus, support is searched in the theoretical references of Hermano Vianna in the work O Misterio do Samba (1995), Feitiço Decente (2012) by Carlos Sandroni, O Terreiro e a Cidade (2002), by Muniz Sodré, among others. In Ana Davenga short story, the samba circle composes the space of the narrative as the place of fun and joy along with the drumming. Anchored in a literary analysis, this article brought reflective results on the interart relations - literature and music, with emphasis on the legacy left by the peoples in our musical tradition.

Keywords: Ana Davenga; Literature and samba; Afro-Brazilian Literature.

\section{INTRODUÇÃO}

O conto Ana Davenga foi publicado em Cadernos Negros, no ano de 1995, e, posteriormente, em Olhos d'água (2016), segundo livro de contos de Conceição Evaristo. O título carrega o nome e o sobrenome das personagens centrais da narrativa: Ana, uma mulher negra, pobre e submissa ao "seu" homem, Davenga, chefe do crime no morro da favela onde vivem.

Figura 1: Capa do livro Olhos d'água (2016)

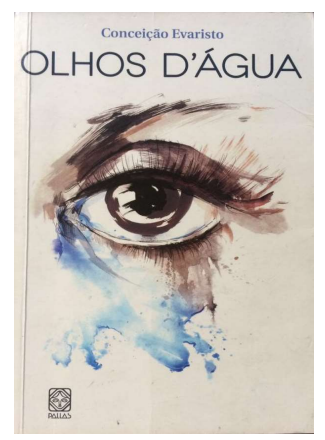

Fonte: Acervo das autoras.

O enredo é permeado pela tensão do início ao fim, histórias que se cruzam por meio de flashbacks. O tema central da narrativa gira em torno da violência na favela, que remete às minorias brasileiras, como negros, pobres e mulheres, trazendo reflexões sobre o feminicídio, a presença do patriarcado, as condições precárias da favela, a falta de oportunidades de emprego e a perspectiva de vida. 
Nossa pretensão não é adentrar o tema da violência, mas procurar dialogar com a história, literatura e música.

A partir disso, encontramos, em Ana Davenga, as relações interartes que abarcam literatura e canção, precisamente o samba, manifestação cultural brasileira, reconhecido como símbolo nacional, conforme atesta o portal do Instituto do Patrimônio Histórico e Artístico Nacional,

As matrizes do Samba no Rio de Janeiro: partido alto, samba enredo e samba de terreiro foram inscritas no Livro de Registro de Formas de Expressão, em 2007. No começo do século XX, a partir de influências rítmicas, poéticas e musicais do jongo, do samba de roda baiano, do maxixe e da marcha carnavalesca, consolidaram-se três novas formas de samba: o partido alto, vinculado ao cotidiano e a uma criação coletiva baseada em improvisos; o samba-enredo, de ritmo inventado nas rodas do bairro do Estácio de Sá e apropriado pelas nascentes escolas de samba para animar os seus desfiles de Carnaval; e o samba de terreiro, vinculado à quadra da escola, ao quintal do subúrbio, à roda de samba do botequim. (IPHAN)

À luz desta citação, interessa-nos, aqui, especial atenção ao festejo da roda de samba, pois no conto, objeto desse estudo, ele aparece ocupando a periferia da favela, área popular urbana.

Nesse sentido, recorremos à pesquisa acadêmica de Hermano Vianna, $O$ Mistério do Samba (1995), que, com seu olhar de historiador, oferece-nos subsídios relevantes sobre a música popular brasileira, precisamente o samba, bem como as concepções teóricas de Carlos Sandroni (2012), Muniz Sodré (2002), entre outros referenciais. No conto Ana Davenga, Evaristo busca resgatar a tradição das rodas de samba por meio da palavra e trazer elementos desse legado histórico para a prosa literária. Segundo a autora, “(...) o samba tem um forte componente negro, tanto na parte melodiosa como na dança (...)" (EVARISTO, 2009, p. 19). Legado que se apresenta da seguinte forma, conforme Evaristo,

Histórias orais, ditados, provérbios, assim como uma gama de personagens do folclore brasileiro, são heranças das várias culturas africanas aqui aportadas e podem ser entendidas como ícones de resistência das memórias 
africanas incorporados à cultura geral brasileira, notadamente a vivida pelo povo. (EVARISTO, 2009, p. 19)

A herança cultural afro-brasileira abarca as mais variadas expressões, para além da música, como vemos no fragmento. Outra personagem relevante para a construção desse legado é a baiana Tia Ciata, grande influenciadora dos festejos de roda de samba no Rio de Janeiro. Segundo Vianna (1995), sua casa foi um ponto de encontro entre vários intelectuais e sambistas, endereço importantíssimo para o nascimento do samba carioca. Assim, a marcação desse espaço de festejo segue toda uma organização, como podemos observar nas falas de testemunhas recuperadas em Feitiço Decente, de Carlos Sandroni (2012, p. 89), "baile na sala de visita, samba de partido-alto nos fundos da casa e batucada no terreiro", afirma o compositor João da Baiana.

Igualmente, nos revela Pixinguinha, "numa festa de pretos havia o baile mais civilizado na sala de visitas, o samba na sala do fundo e a batucada no terreiro" (SANDRONI, 2012, p. 88-89). Não obstante, estava presente na casa também o elemento religioso, ou seja, era um espaço de ancestralidade e prática das crenças. Sob essa ótica, Evaristo resgata, em sua prosa fictícia, essa aproximação das pessoas em torno dos festejos que trazem ideia de alegria, vida, empatia, dentro desse espaço íntimo, que é o barraco de Davenga. É esse íntimo que acolhe a coletividade, seus comparsas, suas famílias, expandindo-se para o espaço íntimo do Outro, no caso a vizinhança: “de repente, naquele minúsculo espaço coube o mundo" (EVARISTO, 2016, p. 21). Nas páginas procedentes, citase:

O barraco de Ana Davenga, como o seu coração, guardava gente e felicidades. Alguns se encostaram pelo pouco espaço do terreiro. Outros se amontoaram nos barracos vizinhos, por onde rolavam a cachaça, a cerveja e o mais e mais. Quando a madrugada afirmou, Davenga mandou que todos se retirassem, recomendando aos companheiros que ficassem alertas. (EVARISTO, 2016, p. 29, grifos nossos) 
Narrado em terceira pessoa, o conto Ana Davenga inicia-se com o prenúncio da celebração da vida, aniversário surpresa para Ana, organizado pelas mulheres e pelos comparsas de Davenga. Ao som das batucadas na porta, anuncia-se todo um ritual de divertimento e alegria, em alusão ao toque dos pandeiros,

As batidas da porta ecoaram como um prenúncio de samba. O coração de Ana Davenga naquela quase meia noite, tão aflito, apaziguou um pouco. Tudo era paz então, uma relativa paz. Deu um salto da cama e abriu a porta. Todos entraram, menos o seu. Os homens cercaram Ana Davenga. As mulheres, ouvindo o movimento vindo do barraco de Ana, foram também. De repente, naquele minúsculo espaço coube o mundo. [...] Um toque diferente, de batidas apressadas, dizia de algo mau, ruim, danoso no ar. $\mathrm{O}$ toque que ela ouvira antes não prenunciava desgraça alguma. Se era assim, onde andava o seu, já que os das outras estavam ali? Por onde andava o seu homem? Por que Davenga não estava ali? (EVARISTO, 2016, p. 21-22)

O toque das batidas, o movimento, a disposição dos homens ao redor de Ana acentuam, no início da narrativa, os festejos da roda de samba dentro do barraco, como já dito. Nota-se mais adiante, por meio de uma sequência de memórias descritas pelo narrador, que os amantes se conheceram em uma roda de samba e terminaram mortos em um festejo de aniversário, onde o batuque do samba é presença marcante.

\section{SAMBA COMO MARCA DA CULTURA AFRO-BRASILEIRA}

O samba é um gênero musical de volume e vibração muito potente. Podemos associar o barulho ao grito do povo, da comunidade que se expressa contra todas as manifestações culturais e os modos de ser do outro. É um gênero que chama atenção, que diz estamos vivos, apesar de tudo. Revela-se como uma marcação de oposição e vivacidade. 
Assim, o samba também foi usado durante muito tempo como forma de cantar a sua dor, como na música-denúncia "tira o teu sorriso do caminho que eu quero passar com a minha dor", do sambista Nelson Cavaquinho. A esse respeito, o samba abarca essa contradição, os dois lados. É notória a correspondência entre essa ambivalência que o samba tem - dor e alegria. $\mathrm{O}$ samba resgata esse sentido e significado.

No governo de Getúlio Vargas, dentro do projeto de nacionalização, época da ditadura, o samba foi transformado em objeto cultural, marca identitária do Brasil, pelo viés da miscigenação, da mistura. O termo identidade foi tema de debates calorosos nos séculos passados, levantando várias posições visionárias pelos críticos da época, conforme nos aponta Vianna (1995, p. 63),

No final do século XIX, o debate intelectual brasileiro já associava a questão da identidade (e da pouca unidade) nacional ao problema do 'atraso' do Brasil, que era comparado à Europa, ponto de referência principal para o pensamento evolucionista dominante na época. [...] O mestiço acabou se transformando no bode expiatório do atraso brasileiro. Os intelectuais da virada do século XIX, pensando dessa maneira, só podiam olhar com desprezo para as manifestações culturais (como os ritmos negros pré-samba ou a feijoada) que décadas depois seriam transformadas em símbolos nacionais e motivo de orgulho e zelo preservacionista para o "povo brasileiro".

De acordo com Vianna, foi Gilberto Freire, em seus estudos teóricos, quem conseguiu dar visibilidade ao mestiço. Assim,

O brasileiro passou a ser definido como a combinação, mais ou menos harmoniosa, mais ou menos conflituosa, de traços africanos, indígenas e portugueses, de casa-grande e senzala, de sobrados e mucambos. (VIANNA, 1995, p. 63)

À luz dessas definições, essa combinação de povos e seus costumes geraram inúmeros conflitos na sociedade brasileira. 
A representação do conto por personagens trágicas, pobres, negras, moradoras da favela, em um contexto social excludente e violento, torna-se significativo, pois retoma as raízes históricas de um tempo sombrio do povo negro. A retomada dos elementos da roda de samba como batidas, toques, movimentos, bateria, dança, sinaliza uma cultura de força. A história narrada na ficção de Evaristo, volta no tempo e cruza com o contexto histórico dos séculos passados. As concepções teóricas trazidas por Vianna em O Mistério do Samba (1995) revelam, na efervescência do século XX, que o cenário não era um dos melhores para a população negra que vivia no Rio de Janeiro, no Pós-Abolição,

O Rio de Janeiro da época estava passando por intensas modificações urbanísticas, desencadeadas pela reforma de Pereira Bastos, com a abertura da Avenida Central e a expulsão de muitas famílias negras e pobres (entre elas muitas famílias baianas que haviam se mudado para o Rio de Janeiro depois da Abolição da Escravatura, trazendo em sua bagagem o candomblé e vários ritmos do samba, que aqui foram transformados no samba carioca) do Centro da cidade para, num primeiro momento, a Cidade Nova e, depois para os subúrbios e favelas. (VIANNA, 1995, p. 112-113)

O fragmento em destaque reafirma a condição de exclusão das famílias pobres e negras das grandes cidades, bem como sua bagagem cultural. Bagagem que foi intensificada e apreciada por vários grupos sociais, mas que gerou preconceitos e perseguições pelas forças policiais.

De acordo com Vianna, no cenário da constituição do gênero musical samba,

a invenção do samba como música nacional foi um processo que envolveu muitos grupos sociais diferentes. $\mathrm{O}$ samba não se transformou em música nacional através dos esforços de um grupo social ou étnico específico, atuando dentro de um território específico ("o morro"). Muitos grupos e indivíduos (negros, ciganos, baianos, cariocas, intelectuais, políticos, folcloristas, compositores eruditos, franceses, milionários, poetas - e até mesmo um embaixador norte-americano) participaram, com maior ou menor tenacidade, de sua "fixação" como gênero musical e de sua nacionalização. (VIANNA, 1995, p. 151) 
Assim, diante do processo de colonização e imigração no Brasil, é notório que essa diversidade de que fala Vianna seja imprescindível para a efetivação das formas culturais existentes.

Para além do oceano, os africanos trazidos para o Brasil como força de trabalho tiveram uma participação significativa na construção da cultura brasileira, ensinando e praticando os seus costumes juntos aos europeus, assim, conforme afirma Evaristo, "[...] coube aos brasileiros, descendentes de africanos, inventarem formas de resistência que marcaram profundamente a nação brasileira" (EVARISTO, 2009, p. 18).

À luz dessas reflexões e por meio de um recuo na história, esses modos de perseguições, levantados por Vianna, já se faziam presentes nas sociedades, à medida que crescia o contato entre os povos e a sua bagagem cultural. Para o negro, isso é mais visível devido às condições de exploração da sua força de trabalho e opressão contra suas crenças e seus divertimentos durante décadas. Para José Ramos Tinhorão, em História Social da Música Popular Brasileira (2010), nos anos seiscentistas do cenário baiano, alguns moralistas, ao observarem os brancos misturados nos festejos dos negros, recriminavam as danças, colocandoos como culpados e desviantes dos honestos, com seus movimentos indecorosos e profanos, fato observado pelo padrão moral da igreja católica.

Surgidas nesses ambientes das mais baixas camadas de Salvador ou de algum dos centros mais populosos do Recôncavo, as danças e cantos estruturados pelas ruas, praças ou terreiros a partir da mistura de elementos rítmicos, melódicos e coreográficos negro-africanos e peninsulares europeus, para atender à nova realidade social da colônia, iniciava então uma espécie de ascensão, através da entrada nas casas das famílias: primeiro as mais modestas ou 'mal construídas', e, depois, nas salas da própria minoria branca da burguesia e dos funcionários do poder real. (TINHORÃO, 2010, p. 92, grifos nossos) 
Notadamente, o crescimento desses modos de divertimento dentro do espaço íntimo vai se tornando uma prática constante nos séculos seguintes, como o exemplo das festividades organizadas na casa de Tia Ciata e outras baianas, e, em especial, no caso em estudo neste artigo, o de Ana Davenga. Não obstante, conforme Muniz Sodré (2002, p. 149), o espaço da casa de Tia Ciata, localizado no cenário urbano carioca era organizado para atender variadas formas de festejos como bailes, samba de partido-alto, batuque e culto, ou seja, era também terreiro, espaço de conexão com as crenças e os ancestrais, como já mencionado.

Sob a ótica do moralista ambulante, Tinhorão resgata:

Uma indicação dessa escalada seria oferecida pelo exemplo citado por Nuno Marques Pereira ao relatar, no Capítulo XVI do seu compêndio narrativo, o "que sucedeu ao Peregrino em casa de um homem que estava em concubinato: e como o aconselhou, para o livrar daquele mau estado". Segundo contava o próprio Peregrino, passara ele em sua caminhada pelo Recôncavo para descansar ao fim da tarde à sombra de uma cajazeira, quando ouviu "em casa do morador afinados instrumentos, sonora música e trincos de castanhetas, como de quem andava dançando". Ali ficou ouvindo os sons alegres até escurecer, quando, finalmente, viu "sair de casa do morador três homens em companhia de três mulheres e algumas escravas" e, avistado pelo dono da casa, foi convidado a entrar. E quando este lhe perguntou porque não se fizera anunciar antes, disse o Peregrino: "Por me livrar (lhe disse eu) de cair em algum pensamento consentido à vista destas danças desonestas e músicas profanas, que hoje se usam, tão agradáveis para o Demônio, como ofensivas contra Deus". (TINHORÃO, 2010, p. 92-93)

Segundo o autor, o observador toma como exemplo para fortalecer suas críticas em torno das músicas e danças desonestas e profanas, um casal que contrariava as regras e a moral da igreja, pois viviam em concubinato, "o que supunha uma posição marginal em relação à sociedade formalmente constituída à base do casamento católico" (TINHORÃO, 2010, p. 93).

Nota-se que as relações de intercâmbio entre os povos da cidade e do campo, oriundos das contínuas emigrações, vieram firmar uma cultura baseada nos mais diversos ritmos, cores, costumes, crenças, isto é, não são parte isolada 
da história, revelam-se diversificadas. A esse respeito, Stuart Hall (2003, p. 29) é incisivo: "na situação da diáspora, as identidades se tornam múltiplas". Prossegue o autor, "nossas sociedades são compostas não de um, mas de muitos povos. Suas origens não são únicas, mas diversas" (HALL, 2003, p. 30).

A música e a dança, como exemplo das práticas culturais dos povos, passaram por vários tipos de transformações. Quando os colonizadores chegaram ao Brasil,

as manifestações culturais que se tornariam típicas das cidades - entre elas a música dirigida às distrações urbanas, mais tarde chamada genericamente de música popular - estavam apenas despontando como algo novo nos principais centros do próprio país descobridor. (TINHORÃO, 2010, p. 15)

Na colônia portuguesa, as festividades de alegria, acompanhadas de gaitas e pandeiros, aconteciam no terreiro, ambiente rural e espaço de labuta de muitos trabalhadores, bem como nas cercanias da capital de Lisboa (TINHORÃO, 2010, p. 17).

Tais cenários aparecem nas imagens pictóricas das páginas precedentes. Com os gentios, desenvolve-se a música de caráter popular, voltada para o gênero religioso. Posteriormente, segundo relembra o autor, na

primeira metade do século XVIII em que vão surgir em Salvador e seu Recôncavo as formas de canto e danças brasileiras destinadas a popularizarse na própria metrópole é também o tempo da explosão urbana provocada na colônia pela corrida às minas [...]. (TINHORÃO, 2010, p. 89)

Dessa época em diante, com as transformações sociais a todo vapor, as manifestações culturais passam por um processo de misturas e inovações contínuas, com destaques para a modinha, o lundu, o maxixe, até chegar ao samba.

Curiosamente, sob o viés literário, o tema do samba foi tratado em romances por vários autores do século XIX, conforme aponta Sandroni (2012). O 
autor recupera como exemplo as obras Til (1872), de José de Alencar, e A Carne (1887), de Júlio Ribeiro. Em sua argumentação, esse corpo negro diaspórico vai aparecer dentro dos romances como um elemento à parte, fora da trama principal da história: em "A Carne só há um capítulo em que os escravos ocupam sozinhos a cena, o de número 10, onde se trata precisamente de um 'samba'" (SANDRONI, 2012, p. 77). A título de exemplificação, o autor cita, “Negros e negras formados em vasto círculo, agitavam-se, palmeavam compassadamente, rufavam adufes aqui e ali. Um figurante, no meio, saltava..." (RIBEIRO, 1887, apud SANDRONI, 2012, p. 77).

Aqui revela-se, segundo o autor, o "samba de umbigada, [...] gesto pelo qual um dançarino designa aquele que irá substituí-lo" (SANDRONI, 2012, p. 75). Na obra de José de Alencar, a presença dos escravos também se dá numa festividade de roda de samba também. Nesse sentido, vejamos o exemplo precedente:

Em torno do samba, Alencar estabelece toda uma sociologia da fazenda paulista: 'os pretos da roça' são os que fazem o samba; os feitores e camaradas, caipiras brancos, ficam à parte ("'bem desejavam os sujeitos entrar na súcia e fazer uma perna no batuque; mas, impedidos pela disciplina da fazenda, contentam-se em olhar de fora'"). (SANDRONI, 2012, p. 80)

De acordo com Sandroni (2012, p. 79), “é a partir da década de 1870 que a palavra 'samba' começa a ser registrada na cidade do Rio de Janeiro". Posto isto, o fragmento da obra literária ambientado na área rural paulista traz como estreia, mesmo que mínima, os momentos festivos do samba promovido por um determinado grupo, os escravizados, oprimidos, tendo como plateia os brancos ou mestiços, que sentem vontade de participar, mas não podem, pois é preciso manter a ordem na fazenda para não incomodar os seus patrões.

O samba a que se refere o autor está associado ao "universo dos negros", com isso, Sandroni (2012, p. 77) traz esses exemplos para ilustrar como 
inicialmente o samba era visto à época da escravidão. Para Sodré (2002, p. 135), a festa tinha para o grupo negro uma força e "[...] os agrupamentos ou as associações controladas não sufocavam a preservação da memória originária ou da criação cultural no meio da escravaria".

Assim, a prosa fictícia de Evaristo ressurge como uma virada de página na história quando coloca os afro-brasileiros como protagonistas na prosa de ficção, sendo parte central, pessoas livres das mordaças, embora presas ao passado da opressão e da violência, revelando os dramas e os conflitos sociais, políticos e culturais de uma coletividade. Diante do exposto, as senzalas foram repaginadas, transportadas para os séculos seguintes na forma de favela, onde esse corpo negro vive, sofre, chora, sonha, sorri, dança, foge, brinca de se esconder das forças repressoras.

\section{PALAVRA, CORPO E RITMO}

As palavras na prosa evaristiana não são as únicas formas de apresentar a existência do afro-brasileiro no mundo, há um corpo e um ritmo que fala, ecoa, reverbera. Para além das palavras, dentro do conto Ana Davenga ocorre a fusão entre corpo e ritmo como forma de marcação da alteridade, sob o viés discursivo da voz feminina afro-brasileira. Essa voz vem romper com tudo aquilo que já foi pensado e escrito sobre os modos de vida do afro-brasileiro. Ela pensa de outra maneira, mas sempre questionando criticamente essas lacunas da opressão. Assim, podemos entender a marcação do samba dentro da narrativa como uma linguagem performática que expressa ideia, como espaço de se colocar e apresentar a sua voz, como sujeito na sociedade.

Comecemos pelo ritmo da narrativa, que não é estática, ela vai e volta, introduzida pela parte final, onde ocorre o desfecho trágico da história, envolvendo felicidade e tristeza, morte e vida. Simbolicamente, essa marca do ir 
e vir remete à ação performática do samba, representada pelo movimento das pernas e dos pés - movimento que vai para um lado e para o outro, embora seja constante, pode ser uma marca de tensão, a partir do momento que não está parado, como podemos observar nos momentos de tensão que Davenga passa, o tempo todo sumido da favela fugindo da polícia -, vai e volta.

Nessa ocasião, os amantes não estão em uma situação de conforto, tanto na vida dela e dele, "às vezes, ficava dias e dias, meses até, foragido, e quando ela menos esperava dava com ele dentro de casa" (EVARISTO, 2016, p. 23). Outra marca interessante dentro da narrativa é o fato de o samba estar ligado à ideia de felicidade positiva que se dá no momento em que ela conhece o amante na roda de samba e na data do seu aniversário, esquecido em sua memória. Ao mesmo tempo em que sente tensão pelo desaparecimento de Davenga, essa tensão muda para felicidade.

A título de exemplificação, cita-se:

O tempo de crescer era breve. O de matar ou morrer chegava breve, também. E o filho dela e de Davenga? Cadê Davenga, meu Deus?

Davenga entra furando o círculo. Alegre, zambeiro, cabeça-sonho, nuvens. Abraça a mulher. No abraço, além do corpo de Davenga, ela sentiu a pressão da arma.

- Davenga, Davenga, que festa é esta? Por que isso tudo?

- Mulher, tá pancada? Parece que bebe? Esqueceu da vida? Esqueceu de você?

[...] Ana estava feliz. Só Davenga mesmo para fazer aquilo. E ela, tão viciada na dor, fizera dos momentos que antecedera a alegria maior um profundo sofrimento. (EVARISTO, 2016, p. 29)

Em Ana Davenga, os movimentos de um corpo negro, esbanjando sensualidade, ganham o espaço da roda de samba, despertando naquele que seria o seu homem, o mais puro desejo:

Quando Davenga conheceu Ana em uma roda de samba, ela estava ali, faceira, dançando macio. Davenga gostou dos movimentos do corpo da mulher. Ela fazia um movimento bonito e ligeiro de bunda. Estava tão 
distraída na dança que nem percebeu Davenga olhando insistentemente para ela. (EVARISTO, 2016, p. 24)

Nota-se, nesse fragmento, que a identidade dos dois começa a se misturar, se atravessar, em um espaço social em que se encontram e um olha para o outro, reconhecendo-se, mesmo nas diferenças se identificam. Depois do encontro, não se largam mais, percebe-se que marcaram esse reconhecimento da diferença, marcaram a alteridade. Ela percebe nele a diferença, percebe nele a humanidade e o desumano - marcas construídas a partir da estrutura social que foi dada a ele.

No conto, o samba no pé, o terreiro da roda de samba, o ritmo ao som das batucadas viram palco de entretenimento de uma comunidade sofrida, que tenta esquecer as marcas do passado e presente. Davenga foi parar na roda de samba depois de se envolver em mais um assalto, na qual a vítima era um deputado:

E de cabeça leve resolveu ir com os amigos para o samba. Sabia, porém, que devia ficar atento. Estava atento, sim. Estava atento aos movimentos e à dança da mulher. Ela lhe lembrava uma bailarina nua, tal qual a que ele vira um dia no filme da televisão. A bailarina dançava livre, solta, na festa de uma aldeia africana. (EVARISTO, 2016, p. 25)

Evidenciam-se, na citação, mais uma vez, o deslumbre e o encantamento de Davenga pelos movimentos faceiros da mulher, em suas reminiscências. Davenga compara Ana a uma bailarina nua, ou seja, eleva a personagem a uma condição superior, uma deusa que enfeitiçava os homens e não como objeto ou algo carnal, imagens corriqueiramente atribuídas às mulheres pela ótica do patriarcado. Assim, o personagem atravessa o Atlântico até chegar em África, em busca de seus ancestrais.

As manifestações culturais que acompanharam esse corpo afro-diaspórico desde África, vindo a se espalhar pelos quatro cantos do mundo, foram tema de muitos estudos, aguçando os mais diversos olhares, como na literatura, nas cartas de cunho moralizador encaminhadas à corte portuguesa, nos olhares pictóricos 
de viajantes artistas europeus como podemos observar nas Figuras 2, 3, 4 e 5, registrados pelo pintor alemão Johann Moritz. A intenção é mostrar como esses corpos negros performáticos aparecem nas festividades elaboradas.

Figura 2: Batuque de negros no Brasil (1835)

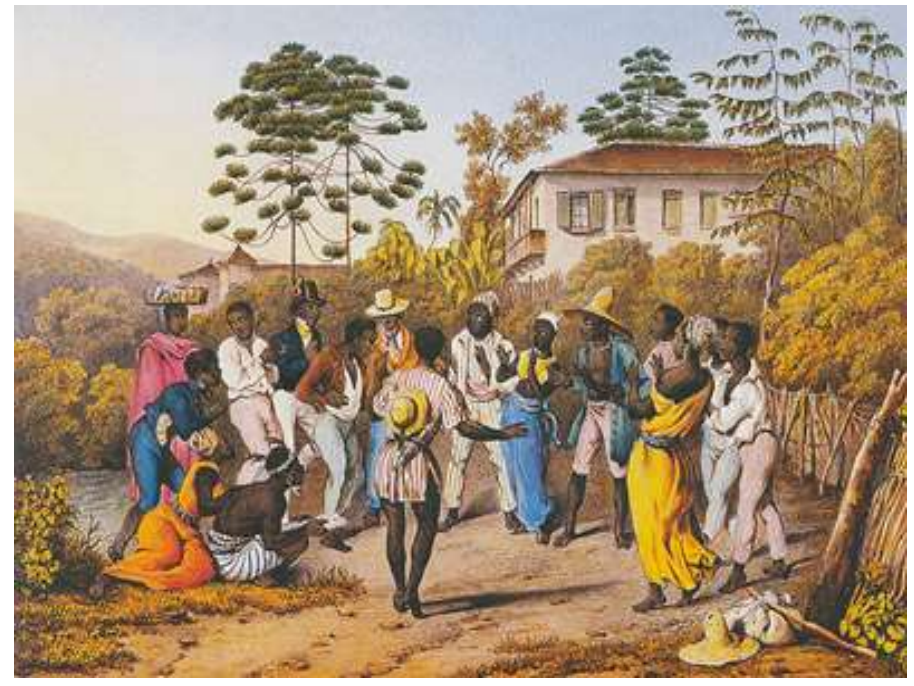

Fonte: Enciclopédia Itaú Cultural.

A ambientação do batuque acontece em um terreiro, provavelmente de uma fazenda. Sugere uma roda de samba pela disposição em círculo, pelo movimento das mãos, haja vista a ausência de algum instrumento musical, e a presença de instrumentos do trabalho como a enxada, chapéu de palha e um tabuleiro na cabeça de um deles. O momento é de alegria, de cantar a sua dor. Sob o olhar do pintor, os negros encontram-se bem vestidos, depois do horário da labuta, fugindo um pouco da realidade retratada.

Cabe ressaltar que, a ideia de corpos negros performáticos desenvolvida no artigo Formas de representação do corpo negro em performance (2018), do autor Marcos Antônio Alexandre, busca mostrar que através das representações ritualísticas dos sujeitos que integram a banda de congo, os corpos se tornam um corpo de memória, pois através da dança e dos movimentos relembram os seus ancestrais e suas crenças, ou seja, "o corpo é fonte de resistência e de propagação da cultura e, claro, de performance" (ALEXANDRE, 2018, p. 5). 
Conforme Sodré (2002, p. 136), “a dança é propriamente integração do movimento ao espaço e ao tempo".

Figura 3: Jogar capoeira (1835)

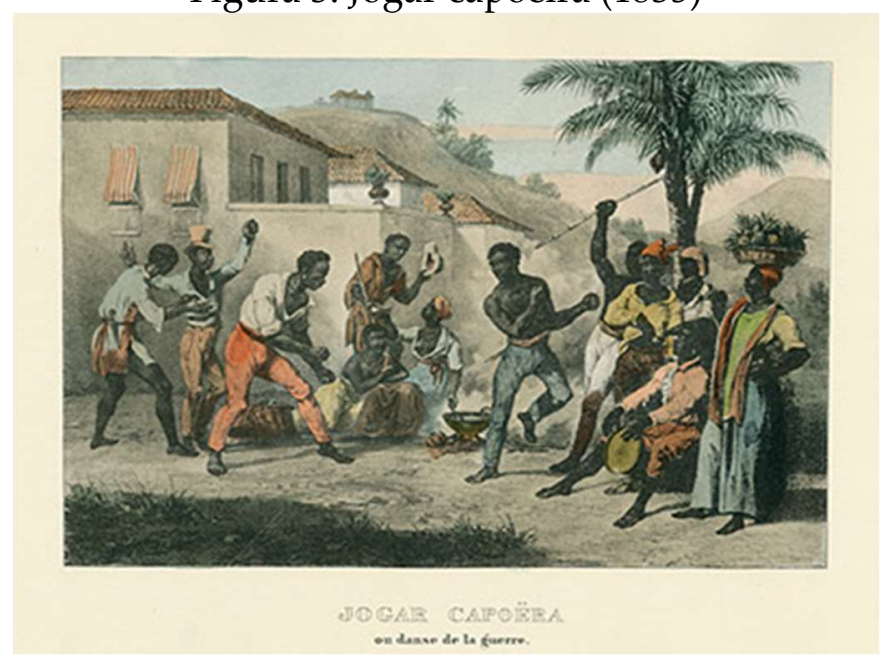

Fonte: Enciclopédia Itaú Cultural.

Na Figura 3, podemos observar a presença de instrumentos musicais, ambiente do terreiro e personagens dispostos em círculo. Os movimentos do corpo e dos pés marcam o para frente e para trás, típico também do samba.

Figura 4: Festa de Santa Rosália, padroeira dos negros (1835)

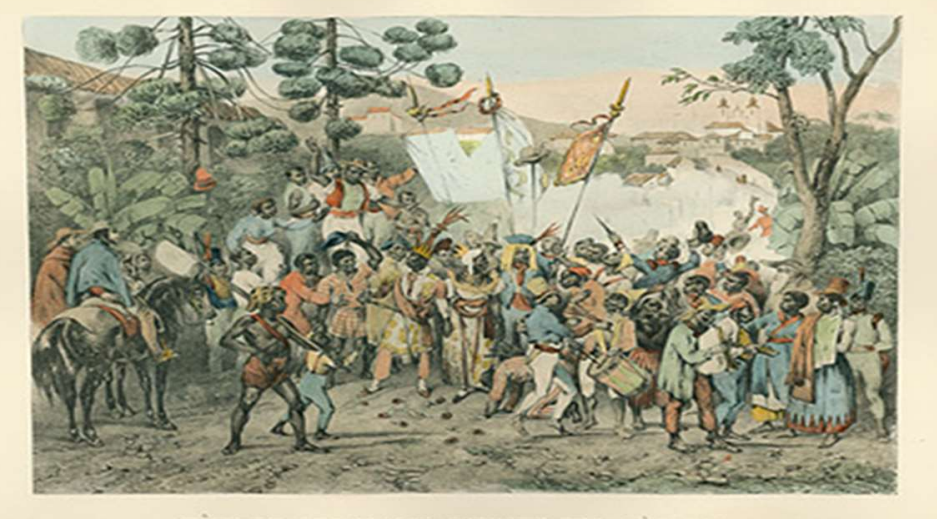

Fonte: Enciclopédia Itaú Cultural.

Na Figura 4, esses corpos performáticos festejam sua crença no espaço do terreiro. Interessante notar que esses festejos, à época, sempre ocorreram ao ar livre. A presença da terra e das plantações funciona como pano de fundo dessas 
festividades. Os personagens estão disponibilizados em uma quantidade maior, espalhados, sem formação de círculo. Observa-se a presença de pandeiros, bandeiras, vestimentas longas, coloridas e simples.

Figura 5: Lundu (1835)

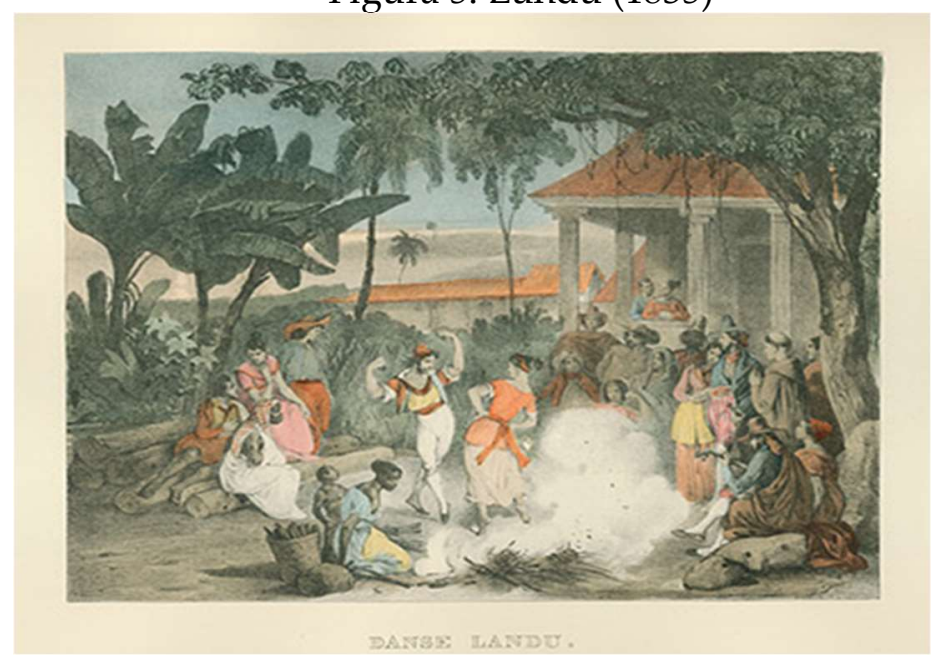

Fonte: Enciclopédia Itaú Cultural.

A última representação pictórica de Moritz nos mostra dispostos em círculo personagens brancos dançando o lundu. $\mathrm{O}$ ambiente é o do terreiro, há poucos personagens negros, mas esses não estão participando da dança, só observam. A figura do casal disposta no canto inferior à direita parece sugerir que o homem está tocando viola. Conforme Vianna (1995, p. 38), “a elite baiana só se dançava o lundu". Segundo o autor, "o lundu é derivado dos ritmos dos batuques dos escravos africanos [...]" (VIANNA, 1995, p. 49). 
Figura 6: Banda de congo Konshaça (2019)³

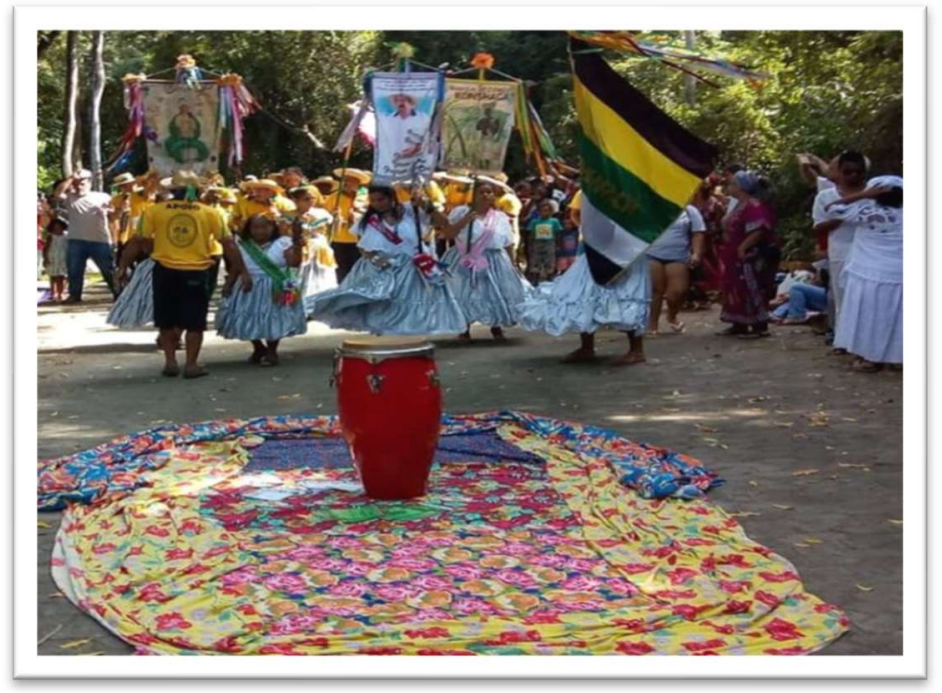

Fonte: Acervo das autoras.

A Figura 6 mostra uma festa religiosa representada pela banda de congo. Conforme Evaristo (2009, p. 18), “[...] a música, a dança, o jogo de capoeira, a culinária e certos modos de vivência religiosa são apontados como aspectos peculiares da nação brasileira [...]". Os personagens afro-brasileiros, a maioria mulheres, dançam o congado nas festividades de Insurreição de Queimado ${ }^{4}$. A ambientação se dá em um espaço simbólico, marcado por histórias de escravização. Os personagens caminham em procissão e param num ponto onde organizam um círculo, com cantorias, palmas rodopios na roda. Bandeiras, mastros e tambores são elementos que compõem a festividade. Assim, vimos, em todas essas manifestações culturais que atravessaram o tempo, um corpo que fala, se movimenta, se organiza e luta. Conforme aponta Alexandre:

Nesses momentos, os corpos dos congadeiros em procissão se convertem em um corpo de memória, sua significância é mais abrangente, representam muito mais que o corpo físico em performance, pois, no momento em que se processa e se vive o ritual, os corpos permitem estabelecer um diálogo entre

3 Banda de Congo de Serra Sede - ES.

4 Insurreição de Queimado é um movimento histórico que envolve a luta dos africanos escravizados nos Espírito Santo, durante o século XIX. Informações retiradas dos sítios: www.serra.es.gov.br e http://www.abcserra.org.br/. 
o passado e o presente, perde-se a dimensão espaço físico-corporal e passa a dimensão espaço memória-corporal. (ALEXANDRE, 2018, p. 4)

Nesse sentido, o corpo negro integra o interior dos festejos e busca sua ancestralidade, passado e presente se cruzam, como bem observado no encontro entre Ana, Davenga e a coletividade afro-brasileira. Os corpos marcam os gestos felizes e os momentos de tensão vividos ao longo de todo o conto. O ritmo e o som das batucadas na porta, prenúncio de samba ou macumba resgatam seus ancestrais e se revelam como se fossem imagens pictóricas formadas na mente de cada receptor.

\section{CONSIDERAÇÕES FINAIS}

Em primeira abordagem foram discutidos no artigo aspectos históricos importantes para compreensão do gênero musical samba, bem como o festejo da roda de samba no conto Ana Davenga, de Conceição Evaristo. Nesse sentido, buscou-se embasamento teórico em Vianna, que com presteza elaborou um estudo acadêmico na década de 1994 voltado para a música, precisamente o samba, posteriormente publicado em livro. Vianna buscou investigar como se deu a nacionalização do samba, voltado para o cenário urbano do Rio de Janeiro.

Na obra, encontramos subsídios teóricos em defesa da "autenticidade do samba", "das mediações transculturais", "do envolvimento entre elite e cultura popular", "do samba como elemento central para definição da identidade nacional", dentre outras inquietações. Ao passo que, em Tinhorão (2010), trouxemos as reflexões em torno das manifestações culturais apontadas no Brasil Colônia, tais concepções teóricas contribuem e nos fazem pensar as relações históricas desempenhando um papel importantíssimo dentro da prosa literária de autoria afro-brasileira. 
Além desse referencial, coube trazer teorias mais recentes como Carlos Sandroni (2012) - que investiga as questões relacionadas ao processo de transformações sofridas pelo samba na virada da década de 1930, o crítico Muniz Sodré (2002) - que em um estudo mais apurado traz um panorama da cultura negra em solo brasileiro, conceitos de terreiro, espaço, territorialidade etc. Em Marcos Antônio Alexandre (2018) encontramos conceitos sobre o corpo performático negro, dentro dos festejos do congado.

Nos registros pictóricos do artista alemão Johann Moritz (1835) verificouse uma cenografia dos espaços ocupados por vários festejos dos povos. Na teoria de Evaristo (2009) foi possível compreender o espaço ocupado pela voz negra feminina na literatura afro-brasileira, cuja leitura do artigo se fez necessária para adentrarmos no universo narrativo de Ana Davenga. Sob esse viés, Evaristo (2009, p. 19) sinaliza,

Pode-se dizer que um sentimento positivo de etnicidade atravessa a textualidade afro-brasileira. Personagens são descritos sem a intenção de esconder uma identidade negra e, muitas vezes, são apresentados a partir de uma valorização da pele, dos traços físicos, das heranças culturais oriundas de povos africanos e da inserção/exclusão que os afrodescendentes sofrem na sociedade brasileira. Esses processos de construção de personagens e enredos destoam dos modos estereotipados ou da invisibilidade com que negros e mestiços são tratados pela literatura brasileira, em geral.

À luz dessas considerações, o conto Ana Davenga carrega em si aspectos que remetem à tradição, que, conforme Sodré (2002, p. 103), é “[...] entendida como o conjunto de saberes transmitido de uma geração para outra $[\ldots]$ ", como podemos observar nos trechos da narrativa: "as batidas na porta ecoaram um prenúncio de samba”; "os homens cercaram Ana Davenga”; "o toque prenúncio de samba ou macumba estava a dizer que tudo estava bem"; "os homens fecharam a roda mais ainda e as mulheres em volta deles começaram a balançar o corpo"; "era samba mesmo"; atravessou o terreiro da roda de samba"; "era uma festa". Cabe destacar que, algumas palavras remetem ao universo dos rituais 
religiosos e aos momentos de divertimento do povo negro. Na parte introdutória do conto, as batidas que de início se alternam entre "samba ou macumba", vêm a se confirmar como "samba mesmo" na página 28.

Desse modo, o espaço do "quartel-general" torna-se um ambiente onde “[...] a festa assegura a passagem de um espaço/tempo a outro [...]" (SODRÉ, 2002, p. 145). Ali, de forma simbólica, os pares experimentam e compartilham alegrias e vivências do cotidiano. Portanto, o legado deixado pelos povos em nossa tradição, revela um universo cultural rico e de grande valor simbólico. As mais variadas produções culturais como a música, a dança, os festejos religiosos, a culinária, a literatura são frutos da luta e da força que, "quanto mais livre sentese um corpo, maior o alcance desse poder de orientar-se por si mesmo, por seus próprios padrões" (SODRÉ, 2002, p. 135).

\section{REFERÊNCIAS}

ALEXANDRE, Marcos Antônio. Formas de representação do corpo negro em performance. In: LITERARFRO: o portal da literatura afro-brasileira. Belo Horizonte: Faculdade de Letras da Universidade Federal de Minas Gerais, 2018. Disponível em: http://www.letras.ufmg.br/literafro/artigos/artigos-teorico-conceituais/156-marcosantonio-alexandre-formas-de-representacao-do-corpo-negro-em-performance. Acesso em: 20 nov. 2020.

EVARISTO, Conceição. Olhos d'água. Rio de Janeiro: Pallas; Fundação Biblioteca Nacional, 2016.

EVARISTO, Conceição. Literatura negra: uma poética da nossa afro-brasilidade. SCRIPTA, Belo Horizonte, v. 13, n. 25, p. 17-31, 2º sem. 2009.

HALL, Stuart. Da diáspora: Identidades e mediações culturais. Belo Horizonte: Editora UFMG, 2003.

IPHAN. Matrizes do samba no Rio de Janeiro: Partido Alto, Samba de Terreiro e SambaEnredo [S. I.]. Disponível em: http://portal.iphan.gov.br/pagina/detalhes/64. Acesso em: 21 mai. 2021.

MORITZ, Johann. Batuque. In: ENCICLOPÉDIA Itaú Cultural de Arte e Cultura Brasileiras. São Paulo: Itaú Cultural, 2021. Disponível em:<http://enciclopedia.itaucultural.org.br/obra2992/batuque>. Acesso em: 13 de fev. 2021. Verbete da Enciclopédia. ISBN: 978-85-7979-060-7. 
MORITZ, Johann. Festa de Santa Rosália, padroeira dos negros. In: ENCICLOPÉDIA Itaú Cultural de Arte e Cultura Brasileiras. São Paulo: Itaú Cultural, 2021. Disponível em: $<$ http://enciclopedia.itaucultural.org.br/obra20252/festa-de-santa-rosalia-padroeira-dosnegros $>$. Acesso em: 13 de fev. 2021. Verbete da Enciclopédia. ISBN: 978-85-7979-060-7.

MORITZ, Johann. Jogar capoeira. In: ENCICLOPÉDIA Itaú Cultural de Arte e Cultura Brasileiras. São Paulo: Itaú Cultural, 2021. Disponível em: $<$ http://enciclopedia.itaucultural.org.br/obra24907/jogar-capoeira>. Acesso em: 19 de mar. 2021. Verbete da Enciclopédia. ISBN: 978-85-7979-060-7.

MORITZ, Johann. Lundu. Viagem Pitoresca através do Brasil, 3/18. In: ENCICLOPÉDIA Itaú Cultural de Arte e Cultura Brasileiras. São Paulo: Itaú Cultural, 2021. Disponível em: $<$ http://enciclopedia.itaucultural.org.br/obra5765/lundu-viagem-pitoresca-atraves-dobrasil-318>. Acesso em: 13 de fev. 2021. Verbete da Enciclopédia. ISBN: 978-85-7979-060-7.

SANDRONI, Carlos. Feitiço Decente. Rio de Janeiro: Jorge Zahar, 2012.

SODRÉ, Muniz. O terreiro e a cidade: a forma social negro-brasileira. Rio de Janeiro: Imago, 2002.

TINHORÃO, José Ramos. História Social da Música Popular Brasileira. São Paulo: Editora 34, 2010.

VIANNA, Hermano. O mistério do samba. Rio de Janeiro: Jorge Zahar Ed; UFRJ, 1995.

Nota do editor:

Artigo submetido para avaliação em: 30 de março de 2021.

Aprovado em sistema duplo cego em: 19 de setembro de 2021. 